\title{
Towards a Division of Labour for Sustainable Development: Extraterritorial Human Rights Obligations
}

\author{
Wouter Vandenhole
}

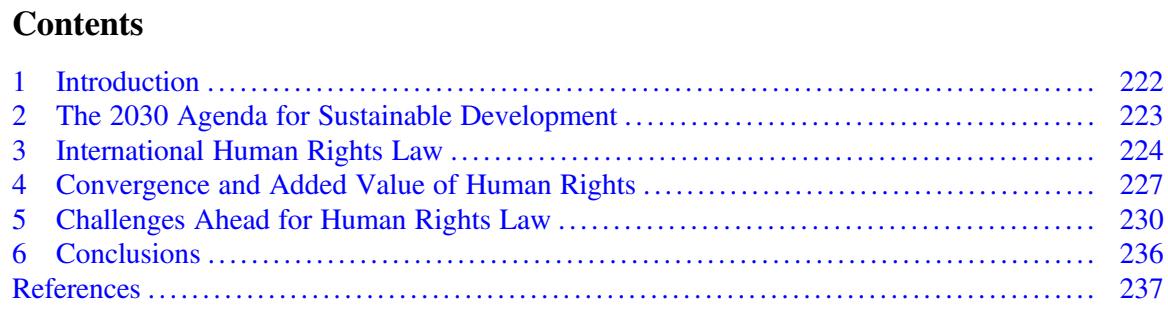

\begin{abstract}
The Sustainable Development Goals (SDGs) adopted in 2015 are the new and ambitious global development agenda for the 2015-2030 period. That global agenda can only be realized through a global effort. What does that mean for the division of labour? Traditionally, fostering development has been seen as the primary responsibility of the territorial State. This chapter reflects from a human rights perspective on the role to be played by external governmental and intergovernmental actors in bringing about sustainable development. It ponders strengths and weaknesses of the right to development and extraterritorial human rights obligations, and identifies five challenges for human rights law: the legal status of the obligations to cooperate internationally; the distributive allocation of extraterritorial obligations; the triggers of extraterritorial human rights obligations; the scope of the extraterritorial obligation to cooperate for development; and the ability of human rights law to engage with strong definitions of development, which take growth agnosticism as their starting point.
\end{abstract}

\footnotetext{
W. Vandenhole $(\triangle)$

Law and Development Research Group, University of Antwerp, Antwerp, Belgium e-mail: wouter.vandenhole@uantwerpen.be 


\section{Introduction}

The Sustainable Development Goals (SDGs) adopted in 2015 are the new and ambitious global development agenda for the 2015-2030 period. That global agenda can only be realized through a global effort. What does that mean for the division of labour? Traditionally, fostering development has been seen as the primary responsibility of the territorial State, with a secondary and often more charity-based role for external actors such as the United Nations organisations, donor countries and non-governmental organisations.

This chapter reflects from a human rights perspective on the role to be played by external governmental and intergovernmental actors in bringing about sustainable development in the context of the SDGs. ${ }^{1}$ Are States $^{2}$ that are in a position to do so, also legally obliged to provide development assistance (ODA), and to what extent: should they simply seek to meet the $0.7 \%$ GNP target, or provide development assistance commensurate to their ability or to global need? Beyond development assistance, do States have more fundamental and encompassing obligations to further sustainable development globally through structural economic and political reforms? When and how are these obligations of external actors triggered: whenever the need arises? Or only when a territorial State is unable and/or unwilling to realize development?

Answers to these questions will be sought primarily in the realm of human rights law. Over the past decades, two main human rights framings have been proposed to analyse the human rights obligations for development of external States: the right to development, and extraterritorial human rights obligations. Both framings are only emerging and major sites of political and legal contestation. Therefore, the legal materials used in this chapter show varying degrees of "legal hardness".

Section 2 explores how the 2030 Agenda for Sustainable Development and the SDGs themselves envisage the division of labour between the territorial State and external State actors. Section 3 introduces the human rights framings of obligations incumbent on external States, that is the right to development and extraterritorial obligations. Section 4 maps the areas of convergence between the Agenda for Sustainable Development and human rights law in this regard, and examines the potential contribution the latter may make in clarifying the role of external State actors in development. Section 5 highlights some of the outstanding debates in human rights law that currently prevent it from taking full normative leadership in the debate on the division of labour for sustainable development. Section 6 concludes.

\footnotetext{
${ }^{1}$ For reasons of space, this chapter does not engage with the question of obligations and responsibility incumbent on non-state actors, such as businesses.

2"States" refers to States acting individually and/or collectively through intergovernmental organisations.
} 


\section{The 2030 Agenda for Sustainable Development}

Transforming our World: the 2030 Agenda for Sustainable Development, the outcome document of the United Nations summit for the adoption of the post-2015 development agenda, acknowledges and emphasizes the importance of a "Global Partnership for Sustainable Development". 3 The idea of a global partnership goes back to the Millennium Declaration and the Millennium Development Goals (MDGs), the 2000-2015 development agenda, in which MDG 8 was dedicated to the development of a global partnership for development. ${ }^{4}$ Among the five "Ps" that the Preamble to the 2030 Agenda for Sustainable Development lists, one is referring to "Partnership". Under that heading, reference is made to "a spirit of strengthened global solidarity" as the foundation for such a partnership. In the Declaration itself, a separate heading is dedicated to the means of implementation, which a revitalized Global Partnership is considered central to. ${ }^{5}$

The starting point for any division of labour for sustainable development nonetheless remains that "each country has primary responsibility for its own economic and social development". Hence, external State actors have only secondary obligations for development. Another element that sheds some light on the envisaged division of labour is the principle of common but differentiated responsibilities, first established in the Rio Declaration on Environment and Development. ${ }^{6}$ This principle of environmental law acknowledges explicitly that not all States are equal, hence the differentiated responsibilities.

Strong emphasis is put in the Declaration on financial resources, with explicit reference to the outcome document of the third International Conference on Financing for Development (held in 2015 in Addis Ababa) and to the long-standing commitment of developed countries to spend $0.7 \%$ of gross national income on official development assistance (ODA). ${ }^{7}$ Elsewhere in the Declaration, some attention is nonetheless also paid to structural challenges in the economic system, where the need for "an enabling international economic environment, including coherent and mutually supporting world trade, monetary and financial systems, and strengthened and enhanced global economic governance" is acknowledged. ${ }^{8}$ In line with this, the targets listed under SDG 17 relate not only to finance, but also to technology transfer, trade and systemic issues of policy and institutional coherence and multistakeholder partnerships.

In sum, primary responsibility of the territorial State is complemented with international solidarity, which is put into practice through official development assistance and an enabling international economic environment. The latter reference

\footnotetext{
${ }^{3}$ UNGA (2015).

${ }^{4}$ UNGA (2010) and United Nations Secretary-General (2001).

${ }^{5}$ UNGA (2015) at paras. 39-46, and 62.

${ }^{6}$ UNGA (2015), at para 12.

${ }^{7}$ UNGA (2015), at paras. 40 and 43.

${ }^{8}$ UNGA (2015), at para 63.
} 
to macro-economic factors, read in conjunction with the principle of common but differentiated responsibilities, may suggest that structural imbalances of power, and hence different degrees of responsibility for mal- and underdevelopment, are being acknowledged.

\section{International Human Rights Law}

In human rights law, two main framings of obligations incumbent on external State actors have taken shape over the past decades, that is the right to development and extraterritorial obligations. Both are briefly introduced in what follows.

\section{The Right to Development}

The concept of a (human) right to development was coined and legally framed in the late 1960s and early 1970s. A Declaration on the Right to Development was adopted in 1986. ${ }^{9}$ Unanimous political recognition to the right to development as a human right was given in 1993, in the Vienna Declaration and Plan of Action. ${ }^{10}$

Justification for the right to development was sought in the strategic, economic and political domination of the North over the global South. This domination made the North responsible for development in the South. ${ }^{11}$

In origin, the right to development was a radical human rights framing of responsibility for development, since it sought to challenge prevailing international economic relations, and to introduce alternative legal principles to guide international relations, such as international solidarity, substantive equality and international justice. ${ }^{12}$ These alternative legal principles relate to the external dimension of the right to development, i.e. the claims to international cooperation and assistance a developing State may have towards external States or the international community, ${ }^{13}$ or the right to have removed structural obstacles to development that are inherent to the prevailing international economic relations. ${ }^{14}$ The latter aspect shows that there was a close connection between the right to development and NIEO, at least in the early years. ${ }^{15}$

\footnotetext{
${ }^{9}$ GA resolution, UN Doc A/RES/41/128 (4 December 1986).

${ }^{10}$ Art. 10 Vienna Declaration and Programme of Action, UN Doc A/CONF.157/23 (12 July 1993).

${ }^{11}$ M'baye (1972), pp. 514-526; M'baye (1980), pp. 78-88.

${ }^{12}$ M'baye (1980), pp. 85-88; Bedjaoui (1987), pp. 95-101; De Vey Mestdagh (1981), pp. 43-44 and 46; Alston (1980), pp. 104-105.

${ }^{13}$ De Feyter (1992), p. 556; Salomon (2008), pp. 2-8.

${ }^{14}$ Marks (1985), p. 509. See Salomon (2008), pp. 8-9.

${ }^{15}$ See, e.g. Abi-Saab (1980), pp. 164-168; Israel (1983), p. 29.
} 
The 1986 Declaration tones down the radical edge of the right to development. Article 3(3) stipulates that "States have the duty to co-operate with each other in ensuring development and eliminating obstacles to development ...", but does not clarify the objectives of that cooperation. Article 4 adds that States "have the duty to take steps, individually and collectively, to formulate international development policies with a view to facilitating the full realization of the right to development". The latter Article also spells out to some extent the division of labour in bringing about development: "As a complement to the efforts of developing countries, effective international co-operation is essential in providing these countries with appropriate means and facilities to foster their comprehensive development."

Recent attempts to elaborate on the right to development's meaning in reference to the global partnership for development in MDG 8, do not add much analytical clarity. ${ }^{16}$ The High Level Task Force set up to assist the UN open-ended working group on the right to development between 2004 and 2010, ${ }^{17}$ elaborated an assessment framework for the extent to which States acting collectively and individually contribute to the creation of an enabling environment for the realization of the right to development. ${ }^{18}$ It has not sought, though, to clarify the distributive allocation of obligations to the territorial State and external States, individually or collectively. ${ }^{19}$ Even more so, in recent attempts at further standard-setting, the external dimension of the right to development, that is the obligations it imposes on external States acting individually and collectively, has been more and more downplayed. ${ }^{20}$

In sum, the 1986 Declaration on the Right to Development focuses mainly on international cooperation, not so much on addressing structural impediments to development. It considers the territorial State as the primary duty-bearer, but a complementary role is envisaged for external States through international cooperation, in particular through international development policies. Later attempts to operationalize the right to development under the MDGs have introduced the notion of an enabling international economic environment, but they do not shed any light on the distributive allocation of development obligations. Let us now turn to human rights law as codified in treaties, to see how responsibility for development is attributed, if at all.

\footnotetext{
${ }^{16}$ Vandenbogaerde (2013), pp. 187-209.

${ }^{17}$ The open-ended working group was established by the UN Commission on Human Rights in 1998.

${ }^{18}$ Report of the high-level task force on the implementation of the right to development on its sixth session (Geneva, 14-22 January 2010), Addendum - Right to development criteria and operational sub-criteria, UN Doc. A/HRC/15/WG.2/TF/2/Add.2 of 8 March 2010.

${ }^{19}$ For an explicit rejection of such an approach, see Report of the high-level task force on the implementation of the right to development on its sixth session (Geneva, 14-22 January 2010), Addendum-Right to development criteria and operational sub-criteria, UN Doc. A/HRC/15/ WG.2/TF/2/Add.2 of 8 March 2010, para. 18.

${ }^{20}$ Vandenbogaerde (2013), pp. 199-200.
} 


\section{Extraterritorial Obligations}

Typically, human rights obligations are incumbent on the territorial State, i.e. the State that exercises territorial jurisdiction. Nonetheless, there is a longstanding recognition that the realisation of at least some human rights-in particular economic, social and cultural rights (ESC rights), children's rights, and the rights of persons with disabilities - requires international cooperation and assistance. ${ }^{21}$ The precise meaning and scope of these references to international cooperation and assistance remain somewhat open to debate, ${ }^{22}$ although a strong case has been made for reading extraterritorial obligations into these references.

The position of the UN Committee on Economic, Social and Cultural Rights (CESCR) on extraterritorial obligations under the ICESCR has been consistent over the past two decades, ${ }^{23}$ and is well-reflected, for example, in its 2016 general comment on the right to sexual and reproductive health. Territorial States that are not able to comply with their obligations due to a lack of resources must seek international cooperation and assistance. "States that are in a position to do so must respond to such requests in good faith and in accordance with the international commitment of contributing at a minimum 0.7 per cent of their gross national income for international cooperation and assistance." Donor States and international actors have an obligation to comply with human rights standards throughout their international assistance (in other words, it should be rights-based), and as members of international organisations and in bilateral, regional and multilateral treaties. ${ }^{24}$ Emphasis was put in an earlier general comment on the right to health on the role of international assistance and cooperation in realizing core obligations and obligations of comparable priority. ${ }^{25}$

Overall, the interpretation of the Committee on the Rights of the Child (CRC Committee) has been very much in line with that of the CESCR, ${ }^{26}$ as illustrated for example in the former's general comment on public budgeting. States that lack the

\footnotetext{
${ }^{21}$ See Article 2 International Covenant on Economic, Social and Cultural Rights; Article 4 Convention on the Rights of the Child; Articles 4 and 32 Convention on the Rights of Persons with Disabilities.

${ }^{22}$ An overview of the UN human rights bodies' understanding can be found in a working paper published by the Global Initiative for Economic, Social and Cultural Rights, Human Rights Law Sources: UN Pronouncements on Extra-Territorial Obligations, July 2015, see http://www. etoconsortium.org/nc/en/main-navigation/library/documents/?tx_drblob_pi1\%5BdownloadUid\% $5 \mathrm{D}=163$ (last accessed 5 January 2018).

${ }^{23}$ For a systematic overview, see Coomans (2011), pp. 1-35.

${ }^{24}$ CESCR, GC No. 22 (2016) on the right to sexual and reproductive health (article 12 of the International Covenant on Economic, Social and Cultural Rights), UN Doc E/C.12/GC/22, 2 May 2016, paras. 50-52.

${ }^{25}$ Social and Cultural Rights Committee on Economic, 'General Comment No. 14 (2000) on the Right to the Highest Attainable Standard of Health (Article 12 of the International Covenant on Economic, Social and Cultural Rights)', (11 August 2000) at para. 45.

${ }^{26}$ For a comprehensive and systematic analysis, see Vandenhole (2009), pp. $23-63$.
} 
resources to fully realize the CRC must seek international cooperation; States with resources "have an obligation to provide such cooperation with the aim of facilitating the implementation of children's rights in the recipient State." ${ }^{27}$ Beyond bilateral development assistance, States "should collaborate with other States' efforts to mobilize the maximum available resources for children's rights." 28 Development cooperation strategies should be rights-based: they should not negatively impact on children, and should contribute to the realisation of children's rights. ${ }^{29}$ State must observe their children's obligations "when engaging in development cooperation as members of international organizations, [footnote omitted] and when signing international agreements.",30

The Committee on the Rights of Persons with Disabilities (CRPD Committee) has mainly emphasized that all cooperation must be rights-based. With regard to the right to inclusive education, this means that "all bilateral and multilateral cooperation must aim to advance inclusive and equitable quality education and promote lifelong learning opportunities for all [...]."31

In sum, the importance of international assistance and cooperation for the realisation of human rights has been acknowledged in several human rights treaties. The reference to international assistance and cooperation has been understood by the UN human rights treaty bodies as imposing an obligation for developing countries to seek, and for developed countries to offer development assistance. Development assistance, international agreements and the exercise of membership of international organizations should all be rights-based. Again, there is little if any clarification of the division of labour for sustainable development. In the next two sections, I will spell out in more detail some aspects of the extraterritorial human rights obligations framing, while looking into in the convergence of the SDGs and human rights, and the challenges ahead.

\section{Convergence and Added Value of Human Rights}

On a number of key points, the 2015 Agenda and the SDGs on the one hand, and human rights law on the other hand, converge and mutually reinforce each other.

First, the need for international cooperation, including international assistance, is acknowledged: development is not exclusively the responsibility of the territorial State. The 2015 Agenda and the SDGs mainly refer to solidarity and a global

\footnotetext{
${ }^{27}$ Committee on the Rights of The Child (2016) at para. 35 .

${ }^{28}$ Committee on the Rights of The Child (2016), at para. 37.

${ }^{29}$ Committee on the Rights of The Child (2016), at para. 38.

${ }^{30}$ Committee on the Rights of The Child (2016), at para. 39.

${ }^{31} \mathrm{CRPD}$, General comment No. 4 (2016) on the right to inclusive education, UN Doc CRPD/C/GC/ 4, 25 November 2016, para. 43. Compare CRPD, GC comment No. 2 (2014) Article 9: Accessibility, UN Doc CRPD/C/2, 22 May 2014, para. 47.
} 
partnership, and seem to envisage mainly multilateral cooperation. The same holds true to some extent for the right to development. The extraterritorial human rights obligations frame focuses more on bilateral cooperation, and in particular on development assistance, although it also pays attention to States acting collectively through international organisations or a treaty regime.

Second, the primary responsibility for development (understood respectively as sustainable development or the full realisation of human rights) lies with the territorial State. External State actors have only a secondary role to play. There is also some differentiation of responsibility: the 2015 Agenda speaks about "shared but differentiated responsibilities" in language borrowed from the Rio Declaration; in the human rights context, the obligations of developing and developed states are different: the latter have to step in when the former are unable to fully realize their obligations and ask the latter for assistance.

Third, it is acknowledged, albeit in various degrees, that development is not just a matter of development finance or development assistance. Attention is given also to economic and financial governance, and to the need for an enabling international economic environment.

Beyond these commonalities, human rights law may be able to further refine the emerging picture of the division of labour for sustainable development in three respects. First, it locates international cooperation more explicitly in the realm of obligation than of charity. Second, it contains more detail on the respective obligations of developing and developed States. And finally, the tripartite typology of human rights obligations may help to clarify the obligations incumbent on external actors in realizing sustainable development. That it may be able is not to say that it currently is already fully up to that task.

Human rights law locates international cooperation and assistance stronger in the realm of (legal) obligation rather than in that of charity. In Fukuda-Parr's view, the challenge for international development policy (at the time as reflected in MDG 8) as already done in human rights law was to "shift international cooperation from charity to solidarity". ${ }^{32}$ Whether that shift has already fully taken place in human rights law, is questionable though. During negotiations on new human rights instruments, this has been a recurrent topic of contestation and politicization. ${ }^{33}$ We will return to this point in Sect. 5.

Second, human rights law spells out in somewhat more detail than the 2015 Agenda and the SDGs what the respective obligations of the territorial and external States are. The territorial State has to undertake measures to the maximum of its available resources to (progressively) fully realize the economic, social and cultural rights guaranteed by the treaties concerned. Where needed, it is under an obligation

\footnotetext{
${ }^{32}$ Fukuda-Parr (2006), p. 967.

${ }^{33}$ With regard to the negotiations on the Optional Protocol to the ICESCR, see Vandenbogaerde and Vandenhole (2010), pp. 227-230. With regard to the negotiations on the CRPD, see Vandenhole (2009), pp. 55-60.
} 
to seek international assistance and cooperation. ${ }^{34}$ In a spirit of fair burden-sharing, the strongest shoulders must bear the heaviest burdens: "economically developed States parties have a special responsibility". ${ }^{35}$ Hence, it is "particularly incumbent upon those States which are in a position to assist" 36 to respond to any request for assistance. In Sect. 5, we will explore what the precise legal status of this obligation is.

Third, the tripartite typology of obligations (to respect, to protect, and to fulfil), when applied to extraterritorial obligations, takes the debate beyond official development assistance and the transfer of financial resources, to more structural factors that inhibit development or create underdevelopment or mal-development. This may be helpful to deepen the understanding of what it takes to create an enabling international economic environment. As the CESCR nicely explains in its 2017 general comment on State obligations in the context of business activities, the extraterritorial obligation to respect requires States "not to obstruct another State from complying with its obligations [...]. This duty is particularly relevant to the negotiation and conclusion of trade and investment agreements or of financial and tax treaties [...]", 37 and-one could add-when exercising membership in regional or international organizations. The extraterritorial obligation to protect implies that the home state of companies has to protect individuals in other countries against adverse impacts of these companies, through e.g. regulation and the use of incentives. $^{38}$ The extraterritorial obligation to fulfil may include an obligation to live up to the longstanding commitment to spend $0.7 \%$ of GNI on official development assistance, but goes clearly beyond that. For CESCR, with regard to State obligations in the context of business activities, it seems to coincide with promoting and creating an international enabling environment. ${ }^{39}$

The account offered here of the reinforcing and clarifying role that human rights law can play with regard to the division of labour for sustainable development may be too optimistic. Much will depend on the way and extent to which human rights law evolves in the coming years. I now turn to the main challenges ahead.

\footnotetext{
${ }^{34}$ Article 2 International Covenant on Economic, Social and Cultural Rights; Article 4 Convention on the Rights of the Child; Article 4(2) Convention on the Rights of Persons with Disabilities.

${ }^{35}$ Committee on Economic, Social and Cultural Rights (2000), para. 40.

${ }^{36}$ Committee on Economic, Social and Cultural Rights (1990) at para. 14.

${ }^{37}$ Committee on Economic, Social and Cultural Rights (2017) at para. 34.

${ }^{38}$ Committee on Economic, Social and Cultural Rights (2017), at para. 36.

${ }^{39}$ Committee on Economic, Social and Cultural Rights (2017), at para. 40.
} 


\section{Challenges Ahead for Human Rights Law}

There are at least five challenges or uncertainties to be addressed in order to make human rights law indeed instrumental in carving out a clear division of labour for sustainable development between territorial States and external actors. These are: the legal status of the obligations to cooperate internationally; the distributive allocation of extraterritorial obligations; the triggers of extraterritorial human rights obligations; the scope of the extraterritorial obligation to cooperate for development; and the ability of human rights law to engage with strong definitions of development, which take growth agnosticism as their starting point.

\section{Aspirational or Hard Legal Obligations?}

There is a long-standing, very often highly politicised and polarised discussion whether or not there is a hard legal obligation to provide international assistance and cooperation, and in particular development aid. In doctrine, two schools have been identified by Karimova: a maximalist and a minimalist one. The maximalist school submits, on the basis of the references to international assistance and cooperation that can be found in treaties, that hard legal extraterritorial obligations exist (for some only negative obligations, for others also positive obligations). In the minimalist approach, international cooperation is not seen as a self-standing and autonomous obligation, but rather as a means or a measure by which obligations can be fulfilled. ${ }^{40}$

Whereas this doctrinal disagreement has not struck much of a chord with the UN treaty bodies, it does correspond to a political disagreement that exists very much along North-South lines. Inevitably, as long as this legal and political disagreement persists, the role of human rights law in carving out a division of labour for sustainable development will be somewhat constrained. In my own reading, informed by more recent treaty negotiations, there is currently no general and undifferentiated hard legal obligation to cooperate internationally for development. On the other hand, an extraterritorial obligation to respect human rights is fairly well accepted. $^{41}$

\footnotetext{
${ }^{40}$ Karimova (2014), pp. 169-171.

${ }^{41}$ See also Vandenhole (2009).
} 


\section{The Distributive Allocation of Obligations Remains Unsettled}

The distributive allocation of obligations plays at two levels: first of all, what the obligations are of the territorial State, and of external States. And secondly, how obligations are allocated among external States.

There is a clear divergence of views on the first question, i.e. the distributive allocation of human rights obligations to the territorial State and external States. For some, the starting point is that all States have global obligations. In their view, human rights are universal: "all people have human rights and [...] all States have the responsibility to protect those rights - for all people". ${ }^{42}$ Hence, the key question is whether the human rights of individuals are respected ${ }^{43}$ or, from a violations perspective, whether "the global order in its entirety" may be to blame for structural impediments to the realisation of human rights. ${ }^{44}$ Whereas this is an interesting theoretical position that deserves further theorisation, it can hardly be grounded in current human rights law.

Another strand of thought considers the territorial State as the primary dutybearer, and external States as secondary or subsidiary duty-bearers. ${ }^{45}$ This position accords well with the fact that the territorial State holds sovereign power over its territory. However, I submit that the obligations of external States are not merely secondary or subsidiary. Rather, they are complementary: these obligations accompany but never replace a territorial State's obligation. The term "secondary" suggests a hierarchy or sequence of obligations, as if extraterritorial human rights obligations arise only in the event that the territorial State failed to observe its obligations. "Complementary" recognises that a State's extraterritorial obligations co-exist simultaneously with the territorial State's obligations, whereas it accepts that the latter's obligations remain primary. ${ }^{46}$

Taking the analysis one step further, it is suggested to differentiate the distributive allocation of obligations between the territorial State and external States with the type of obligation. Since profound resource implications, including financial, become more likely as we move on the obligations continuum from respect and protect to fulfil, I consider the extraterritorial obligations to respect and to protect as complementary and simultaneous, and the extraterritorial obligation to fulfil as subsidiary. ${ }^{47}$ Simultaneous obligations are immediate obligations, lack of observance of which cannot be justified by invoking non-abidance with the primary

\footnotetext{
${ }^{42}$ Gibney (Reference) at 47.

${ }^{43}$ Skogly (2006), p. 48.

${ }^{44}$ See also Salomon (2006), pp. 113, 116; Pogge (2002).

${ }^{45}$ See, for example, Craven (1995), p. 144; Coomans (2004), p. 198; Sepúlveda (2003), pp. 370-377 (implicitly).

${ }^{46}$ Compare Vandenhole and Benedek (2013), pp. 332-366.

${ }^{47}$ Compare Alston's notion of a correlative obligation in case a developing country has demonstrated its best efforts to meet the Millennium Development Goals (MDGs) but is unable to do so because of a lack of financial resources, Alston (2005), pp. 755-829, at 778.
} 
obligation by the territorial State. The extraterritorial obligation to fulfil (like the territorial State's obligation to fulfil) fundamentally requires the mobilisation of resources, and is therefore in principle not an immediate obligation, but one that is subject to progressive realisation in light of the (maximum use of) available resources. $^{48}$

If, in a specific case, the resource implications assumption with regard to the extraterritorial obligations to fulfil, or the relatively resource-free implications assumption underlying the extraterritorial obligations to respect and to protect, can be rebutted, the assessment of the subsidiary or simultaneous nature of the extraterritorial obligations may have to be adjusted.

The division of responsibility between external States, in particular in the field of international development co-operation, is very much a de lege ferenda exercise. No particular problems arise with regard to the obligation to respect, which is a negative obligation that is simultaneously incumbent on (each territorial State and) all external States. The obligation to protect is also of simultaneous application, but may have more far-reaching implications for some States commensurate to their capacity. The obligation to protect may sometimes amount to a joint obligation, that is when individual extraterritorial obligations would not be sufficient. ${ }^{49}$ This may be the case when policies of international financial institutions or of the European Union are considered to be an unjustifiable interference with ESC rights. With regard to the division of responsibility amongst external States under the extraterritorial obligation to fulfil, it is not sufficient to identify "a generic [obligation] that attaches to the undifferentiated international community". 50 Duty-bearers are to be identified in more detail. Whether a State is in a position to assist depends inter alia on the availability of resources, be they human, natural, financial or other. ${ }^{51}$ This is not to say that the extraterritorial obligation to fulfil never requires collective or joint observance in order to be effective. However, as the obligation to fulfil is most likely to have some resource implications, even when considered to be a joint obligation of a number of States, it is necessary to specify which external States are concerned and what the extent of their obligations is. In order to be able to do so, further clarification is needed on how extraterritorial obligations of States are triggered.

\footnotetext{
${ }^{48}$ Certain exceptions to the principle of progressive realisation may apply, such as non-discrimination and core obligations. For more details, see, for example, Vandenhole (2003), pp. 437-438 and 441-442.

${ }^{49}$ Künnemann (2004), p. 220.

${ }^{50}$ See Alston (2005), p. 777: "The nature of any obligation that could reasonably be argued to have emerged from the various commitments to cooperate internationally is, at best, a generic one that attaches to the undifferentiated international community."

${ }^{51}$ Engh (2008).
} 


\section{Triggers of Extraterritorial Fulfil Obligations Need to Be Defined More Clearly}

A diversity of triggers can be considered. It may be the mere ability of the external State(s), as proponents of global human rights obligations suggest. Or it may be the request by a territorial State that is unable to realize human rights on its own. Other triggers that have been suggested are causation of human rights harm, ${ }^{52}$ or historical responsibility.

The domestic State's inability, for reasons beyond its control, to abide by its obligation to fulfil the minimum core content of ESC rights would correspond partly to the CESCR's threshold for activating the obligation to fulfil (provide) for a territorial State. ${ }^{53}$ The extraterritorial obligation to fulfil, like the domestic obligation to fulfil, is subject to progressive realisation in light of the maximum of available resources. It is, in other words, not an immediate obligation, but rather one qualified by time and resources. However, upon the receipt of a legitimate request, there is an immediate obligation for States in a position to assist to take steps to contribute to the progressive realisation in the affected State.

The applicability of extraterritorial obligations of fulfilment should not be conditioned by the reasons for noncompliance by the territorial State. Unwillingness or lack of commitment does not necessarily exonerate other States from taking action. ${ }^{54}$ This does not make external States the de facto primary duty-bearers. The territorial State remains responsible for noncompliance with its obligation to fulfil ESC rights to the maximum extent of its available resources. The action taken by external States reflects their living up to their part of responsibility: their extraterritorial obligations of fulfilment remain subsidiary, constrained by the availability of resources and arguably limited to the core obligations. ${ }^{55}$ Hence, the applicability of extraterritorial obligations of fulfilment should not be conditioned by whether the territorial State fully complies with its own primary obligations, regardless of the reasons for this noncompliance (be it inability or unwillingness). However, their scope is not

\footnotetext{
${ }^{52}$ Skogly (2013), pp. 233-258.

${ }^{53}$ See, for example, Committee on Economic, Social and Cultural Rights (1999), para 15: "whenever an individual or group is unable, for reasons beyond their control, to enjoy the right to adequate food by the means at their disposal, States have the obligation to fulfil (provide) that right directly". The reference to "beyond their control" was borrowed from Art. 25(1) of the Universal Declaration on Human Rights.

${ }^{54}$ Compare on the external obligations of a supranational organization like the European Union (EU), Hazelzet (2007), p. 401: "It is argued, moreover, that the EU's external duties, for instance in the area of trade and development, should not be conditional on the fulfilment of obligations by states in the South, because the EU's international assistance and cooperation, ultimately, are to the people in the South, with the state being the intermediary through which their rights can most often be realised."

${ }^{55}$ As the CESCR has repeatedly suggested, see Committee on Economic, Social and Cultural Rights (2002) at para. 38; Committee on Economic, Social and Cultural Rights (2006) at para. 40; Committee on Economic, Social and Cultural Rights (2008), para. 61.
} 
extended when a territorial State fails to live up to its part. For example, the fact that a territorial State is reluctant to provide free basic health care to all individuals does not exonerate other States from fulfilling their extraterritorial obligations in this regard, albeit limited to their share. How the scope of the extraterritorial obligation to fulfil-provide can be defined, is discussed in the next sub-section.

\section{Scope of the Obligation to Cooperate for Development}

The scope of the extraterritorial obligation to fulfil-provide can be defined by the resources available to a State. Resources include not only financial, but also natural and human resources, as well as, for example, technology, logistics and information. ${ }^{56}$ Nonetheless, financial resources will often play an important role.

Availability of resources is primarily assessed by the State concerned, which enjoys a margin of appreciation in the allocation of its resources. A prima facie assessment of financial resources an external State has available to cooperate for development may be based primarily on the allocations actually made in the national budget for ODA and for emergency aid. A more comprehensive assessment should go beyond national allocations. For example, political or legal commitments made in internal development policies, domestic legislation or bilateral agreements may all be indicative of the financial resources an external State can be expected to mobilize under its extraterritorial obligation to fulfil-provide. One can think there of the oft-repeated political commitment of spending $0.7 \%$ of GNI on development assistance. Other commitments made, for example, in the context of conferences regarding financing for development can equally help to settle the scope of the extraterritorial obligation to fulfil, both as a collective obligation and as one incumbent on particular States.

In its Statement on Poverty, CESCR submitted that "core obligations give rise to ... international responsibilities for developed States, as well as others that are 'in a position to assist" ${ }^{57}$ Core obligations hence seem to have been elevated to the level of global human rights obligations.

Extraterritorial human rights obligations to co-operate internationally for development should not be drawn too narrowly, though. Development assistance is but one feature of the obligation to co-operate internationally for development. Beyond the obligation to fulfil-provide, all types of obligations may be relevant. For example, as part of the extraterritorial obligation to respect, a human rights impact assessment may have to be undertaken of all policies with external effects. As part of the obligation to fulfil-facilitate, structural measures in trade, finance and investment regimes may be needed.

\footnotetext{
${ }^{56}$ Compare Engh (2008).

${ }^{57}$ Committee on Economic, Social and Cultural Rights (2001), para. 16.
} 


\section{Sustainable Development and Growth Agnosticism}

A fifth challenge for human rights law is to take sustainable development, particularly in its strong definitions, seriously.

In the 2030 Agenda, economic growth, social development and ecological sustainability go hand in hand. Commonly, sustainable development is explained in terms of a triple bottom-line (the three Ps of profit, planet and people), suggesting that it is about balancing economic growth with environmental and social considerations. In other words, economic growth is still taken for granted.

This approach of balancing planet and people with profit may be seen as the weak definition of sustainability. Strong definitions of sustainability deplore that sustainable development means "environmentally friendly economic growth" ${ }^{58}$ In these strong definitions, the prevalence of the environmental dimension over the economic one is argued for. ${ }^{59}$ The prioritization of the environmental (planet) over the economic (profit) one ${ }^{60}$ has led to a radical departure from assumptions of economic growth, including zero-growth or even de-growth, as argued in post-growth or ecological economics. ${ }^{61}$ At the very least, growth agnosticism, as adopted by Raworth in "Doughnut Economics", 62 replaces growth as the new normal.

At first sight, growth agnosticism seems to undercut the foundation of social development. If economic growth is no longer the basis of social development, what is? Or does growth agnosticism lead to a major roll-back in socio-economic rights realization? The latter is certainly not the option that is defended. In "Doughnut Economics", it is between the outer boundary, i.e. the ecological ceiling (composed of Roxtrom et al.'s nine planetary boundaries) and the inner boundary, i.e. the social foundation (twelve social boundaries drawing on "internationally agreed minimum social standards"), that "lies an environmentally safe and socially just space in which humanity can thrive." ${ }^{, 63}$ The basis for that environmentally sustainable and socially just space is to be found in redistribution, domestically and globally.

For sure, the call for global redistribution and fair shares of effort reinforces the earlier analysis in this chapter that if the SDGs are to become a reality, redistribution of some sort through international assistance and cooperation will be needed. But growth agnosticism also challenges human rights law, since the latter is very much based on assumptions of growth that translate into progressive realisation of ESC

\footnotetext{
${ }^{58}$ Kerschner (2010), p. 549.

${ }^{59}$ Bosselmann (2011), p. 54; compare the argument that the SDGs need to be organized in a normative hierarchy, with a single priority sustainability goal at the apex', see Kim and Bosselmann (2015), p. 198; on the nine planetary boundaries, see the Stockholm resilience Centre http://www. stockholmresilience.org/research/planetary-boundaries.html (accessed July, 3 2017).

${ }^{60}$ Bosselmann (2011); Ross (2009), pp. 32-54.

${ }^{61}$ For arguments about the desirability and feasibility of degrowth, see the references in Kallis et al. (2012), pp. 173-175.

${ }^{62}$ Raworth (2017b), pp. 243-285.

${ }^{63}$ Raworth (2017a).
} 
rights. This requires a major shift in attention towards redistribution and redistributive equality, concepts that so far have remained un- or under theorised in human rights law. As submitted by Alston, the human rights community has closed it eyes to what has been coined extreme or radical inequality, ${ }^{64}$ and it remains to be seen whether human rights law can do more than offering "a floor of protection against indigence", that is whether it can provide "a ceiling on inequality", as Moyne has pleaded for. ${ }^{65}$

\section{Conclusions}

The ambition of this chapter was to show how human rights law can be of help to the SDGs to operationalise the global partnership for development. That global agenda can only be realized through a global effort. What does that mean for the division of labour? Traditionally, fostering development has been seen as the primary responsibility of the territorial State, with a secondary and often more charity-based role for external actors such as the United Nations organisations, donor countries and non-governmental organisations. That legacy is reflected in the SDG Declaration.

Whereas the concept of the right to development was meant to address structural impediments to development, the 1986 Declaration on the Right to Development focuses mainly on international cooperation. Later attempts to operationalize the right to development under the MDGs have introduced the notion of an enabling international economic environment, but they do not shed any light on the distributive allocation of development obligations.

The reference to international cooperation and assistance in human rights treaties has been interpreted by the UN human rights treaty bodies as imposing an obligation for developing countries to seek, and for developed countries to offer development assistance. Development assistance, international agreements and the exercise of membership of international organizations should all be rights-based. Here too, there is little if any clarification of the division of labour for sustainable development.

So, beyond the areas of convergence in the SDGs and human rights law, at least five challenges or uncertainties must be addressed in order to make human rights law indeed instrumental in carving out a clear division of labour for sustainable development between territorial States and external governmental actors. These are: the legal status of the obligations to cooperate internationally; the distributive allocation of extraterritorial obligations; the triggers of extraterritorial human rights obligations; the scope of the extraterritorial obligation to cooperate for development; and the ability of human rights law to engage with strong definitions of development,

\footnotetext{
${ }^{64}$ Alston (2017): 'Extreme inequality should also be seen as a cause for shame on the part of the international human rights movement. Just as global economic institutions have eschewed human rights, so too have the major human rights groups avoided tackling the economics of rights.'

${ }^{65}$ Moyne (2015, 2017).
} 
which take growth agnosticism as their starting point. The jury is out whether human rights law will evolve in these directions.

\section{References}

Abi-Saab G (1980) The legal formulation of a right to development. In: Dupuy R-J (ed) Le droit au développement au plan international. Nijhoff, The Hague, pp 159-175

Alston P (1980) The right to development at the international level. In: Dupuy R-J (ed) Le droit au développement au plan international. Nijhoff, The Hague, pp 99-114

Alston P (2005) Ships passing in the night: the current state of the human rights and development debate seen through the lens of the Millennium Development Goals. Hum Rights Q 27 (3):755-829

Alston P (2017) Extreme inequality as the antithesis of human rights. Opendemocracy.net

Bedjaoui M (1987) Some unorthodox reflections on the "right to development". In: Snyder F, Slinn $\mathrm{P}$ (eds) International law of development: comparative perspectives. Professional Books, Abingdon, pp 87-116

Bosselmann K (2011) A vulnerable environment: contextualising law with sustainability. J Hum Rights Environ 2(1):45-63

Committee on Economic, Social and Cultural Rights (1990) General Comment No. 3: The nature of States parties obligations (Art. 2, par. 1)

Committee on Economic, Social and Cultural Rights (1999) General Comment 12, Right to Adequate Food (Twentieth Session, 1999), UN Doc. E/C.12/1999/5

Committee on Economic, Social and Cultural Rights (2000) General Comment No. 14 (2000) on the right to the highest attainable standard of health (article 12 of the International Covenant on Economic, Social and Cultural Rights)

Committee on Economic, Social and Cultural Rights (2001) Statement on Substantive Issues Arising in the Implementation of the International Covenant on Economic, Social and Cultural Rights: Poverty and the International Covenant on Economic, Social and Cultural Rights (4 May 2001), UN Doc. E/C.12/2001/10

Committee on Economic, Social and Cultural Rights (2002) General Comment No. 15, The right to water (arts. 11 and 12)

Committee on Economic, Social and Cultural Rights (2006) General Comment 17, The Right of Everyone to Benefit from the Protection of the Moral and Material Interests Resulting from any Scientific, Literary or Artistic Production of Which He or She Is the Author

Committee on Economic, Social and Cultural Rights (2008) General Comment 19, The Right to Social Security (Art. 9)

Committee on Economic, Social and Cultural Rights (2017) General Comment No. 24 on State Obligations under the International Covenant on Economic, Social and Cultural Rights in the Context of Business Activities

Committee on the Rights of the Child (2016) General Comment No. 19 (2016) on public budgeting for the realization of children's rights (art. 4)

Coomans F (2004) Some remarks on the extraterritorial application of the international covenant on economic, social and cultural rights. In: Coomans F, Kamminga MT (eds) Extraterritorial application of human rights treaties. Intersentia, Antwerp

Coomans F (2011) The extraterritorial scope of the international covenant on economic, social and cultural rights in the work of the United Nations Committee on economic, social and cultural rights. Hum Rights Law Rev 11(1):1-35

Craven M (1995) The international covenant on economic, social, and cultural rights: a perspective on its development. Oxford University Press, Oxford

De Feyter K (1992) The human rights approach to development. Universitaire Instelling Antwerpen 
de Vey Mestdagh K (1981) The right to development. Neth Int Law Rev 28(01):30-53

Engh I-E (2008) Developing capacity to realizse socio-economic rights. The right to food in the context of HIV/AIDS in South Africa and Uganda. Intersentia, Antwerp

Fukuda-Parr S (2006) Millennium Development Goal 8: indicators for international human rights obligations? Hum Rights Q 28(4):966-997

Hazelzet $\mathrm{H}$ et al (2007) New human rights duty-bearers: a conversation on policy implications. In: Salomon M, Tostensen A, Vandenhole W (eds) Casting the net wider: human rights, development and new duty-bearers. Intersentia, Antwerp, pp 395-416

Israel J-J (1983) Le droit au développement. Revue Générale de Droit International Public 87:6-41

Kallis G, Kerschner C, Martinez-Alier J (2012) The economics of degrowth. Ecol Econ 84:172-180

Karimova T (2014) The nature and meaning of 'International Assistance and Cooperation' under the international covenant on economic, social and cultural rights. In: Riedel E, Giacca G, Golay $\mathrm{C}$ (eds) Economic, social, and cultural rights in international law. Contemporary issues and challenges. Oxford University Press, Oxford, pp 163-192

Kerschner C (2010) Economic de-growth vs. steady-state economy. J Clean Prod 18(6):544-551

Kim RE, Bosselmann K (2015) Operationalizing sustainable development: ecological integrity as a grundnorm of international law. Rev Eur Comp Int Environ Law 24(2):194-208

Künnemann R (2004) Extraterritorial application of the international covenant on economic, social and cultural rights. In: Coomans F, Kamminga MT (eds) Extraterritorial application of human rights treaties. Intersentia, Antwerp

M'Baye K (1972) Le droit au développement comme un droit de l'homme. Revue des droits de l'homme V(2-3):505-534

M’Baye K (1980) Le droit au développement. In: Dupuy R-J (ed) Le droit au développement au plan international. Nijhoff, The Hague, pp 72-93

Marks S (1985) Emerging human rights: a new generation for the 1980s? In: Falk R, Kratochwil F, Mendlovitz S (eds) International law: a contemporary perspective. Westview, Boulder, pp $501-513$

Moyne S (2015) Human rights and the age of inequality. opendemocracy.net (2017)

Pogge T (2002) World poverty and human rights: cosmopolitan responsibilities and reforms

Raworth K (2017a) The Doughnut of social and planetary boundaries (2017). <https://www. kateraworth.com/doughnut/>. Accessed 3 July 2017

Raworth K (2017b) Doughnut economics. Seven ways to think like a 21st-century economist. Random House Business Books, London

Ross A (2009) Modern interpretations of sustainable development. J Law Soc 36(1):32-54

Salomon M (2006) International human rights obligations in context: structural obstacles and the demands of global justice. In: Andreassen BA, Marks SP (eds) Development as a human right: legal, political, and economic dimensions. Harvard University Press, Cambridge, MA

Salomon M (2008) Legal cosmopolitanism and the normative contribution of the right to development. LSE Law, Society and Economy Working Papers 16/2008. London School of Economics and Political Science, London

Secretary-General, United Nations (2001) Road map towards the implementation of the United Nations Millennium Declaration

Sepúlveda M (2003) The nature of the obligations under the international covenant on economic, social and cultural rights. Intersentia, Antwerp

Skogly S (2006) Beyond National borders. States' human rights obligations in international cooperation. Intersentia, Antwerp

Skogly S (2013) Causality and extraterritorial human rights obligations. In: Langford M et al (eds) Global justice, state duties: the extraterritorial scope of economic, social and cultural rights in international law. Cambridge University Press, New York, pp 233-258

UNGA (2010) United Nations Millennium Declaration

UNGA (2015) Transforming our world: the 2030 Agenda for Sustainable Development

Vandenbogaerde A (2013) The right to development in international human rights law: a call for its dissolution. Neth Q Hum Rights 31(2):187-209 
Vandenbogaerde A, Vandenhole W (2010) The optional protocol to the international covenant on economic, social and cultural rights: an ex ante assessment of its effectiveness in light of the drafting process. Hum Rights Law Rev 10(2):207-237

Vandenhole W (2003) Completing the UN complaint mechanisms for human rights violations step by step: towards a complaints procedure to the international covenant on economic, social and cultural rights. Neth Q Hum Rights 21:423-462

Vandenhole W (2009) Economic, social and cultural rights in the CRC: is there a legal obligation to cooperate internationally for development? Int J Child Rights 17:23-63

Vandenhole W, Benedek W (2013) Extraterritorial human rights obligations and the north-south divide. In: Langford $\mathrm{M}$ et al (eds) Global justice, state duties: the extraterritorial scope of economic, social and cultural rights in international law. Cambridge University Press, New York, pp 332-366

Wouter Vandenhole teaches human rights law at the University of Antwerp. He chairs the Law and Development research group at the Faculty of Law. Mr. Vandenhole graduated in law at the University of Leuven (Belgium), received an LL.M. in Law in Development from the University of Warwick (United Kingdom) and holds a PhD of the University of Leuven. He has previously held positions at the University of Leuven, Tilburg University (the Netherlands) and the European Master's Degree in Human Rights and Democratisation (Venice, Italy). His research interests include children's rights, human rights, in particular economic, social and cultural rights, and the relationship between human rights law and development. For some years now, he has focused on transnational human rights obligations, i.e. the human rights obligations of new duty-bearers, and in particular on companies.

Open Access This chapter is licensed under the terms of the Creative Commons Attribution 4.0 International License (http://creativecommons.org/licenses/by/4.0/), which permits use, sharing, adaptation, distribution and reproduction in any medium or format, as long as you give appropriate credit to the original author(s) and the source, provide a link to the Creative Commons licence and indicate if changes were made.

The images or other third party material in this chapter are included in the chapter's Creative Commons licence, unless indicated otherwise in a credit line to the material. If material is not included in the chapter's Creative Commons licence and your intended use is not permitted by statutory regulation or exceeds the permitted use, you will need to obtain permission directly from the copyright holder.

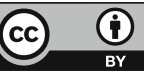

